Programming and Problem-solving in Algol 68 
Macmillan Computer Science Series

\section{Consulting Editor}

Professor F.H. Sumner, University of Manchester

S.T. Allworth, Introduction to Real-time Software Design

Ian O. Angell, A Practical Introduction to Computer Graphics

G.M. Birtwistle, Discrete Event Modelling on Simula

T.B. Boffey, Graph Theory in Operations Research

Richard Bornat, Understanding and Writing Compilers

J.K. Buckle, The ICL 2900 Series

J.K. Buckle, Software Configuration Management

Derek Coleman, A Structured Programming Approach to Data*

Andrew J.T. Collin, Fundamentals of Computer Science

Andrew J.T. Colin, Programming and Problem-solving in Algol 68*

S.M. Deen, Fundamentals of Data Base Systems*

J.B. Gosling, Design of Arithmetic Units for Digital Computers

David Hopkin and Barbara Moss, Automata*

Roger Hutty, Fortran for Students

H. Kopetz, Software Reliability

A. Learner and A.J. Powell, An Introduction to Algol 68 through Problems*

A.M. Lister, Fundamentals of Operating Systems, second edition*

G.P. McKeown and V.J. Rayward-Smith, Mathematics for Computing

Brian Meek, Fortran, PL/I and the Algols

Derrick Morris and Roland N. Ibbett, The MU5 Computer System

John Race, Case Studies in Systems Analysis

B.S. Walker, Understanding Microprocessors

I.R. Wilson and A.M. Addyman, A Practical Introduction to Pascal 


\title{
Programming and Problem-solving in Algol 68
}

\author{
Andrew J. T. Colin \\ Professor of Computer Science, \\ University of Strathclyde
}

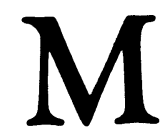

Macmillan Education 
(c) Andrew J. T. Colin 1978

All rights reserved. No part of this publication may be reproduced or transmitted, in any form or by any means, without permission.

First edition 1978

Reprinted 1981, 1984

Published by

THE MACMILLAN PRESS LTD

London and Basingstoke

Companies and representatives throughout the world

British Library Cataloguing in Publication Data

Colin, Andrew John Theodore

Programming and problem-solving in Algol 68.

-(Macmillan computer science series).

1. ALGOL (Computer program language)

I. Title II. Series

001.6'424 QA76.73.A24

ISBN 978-0-333-23115-9

ISBN 978-1-349-03561-8 (eBook)

DOI 10.1007/978-1-349-03561-8 


\section{Contents}

Preface vii

Note on Exercises viii

1 Computers and Problem-solving 1

2 Information Storage and Processing $\quad 12$

3 Introduction to Algol $68 \quad 22$

4 Conditionals $\quad 42$

5 Loops and Program Efficiency 55

$\begin{array}{lll}6 & \text { Program Structure } & 70\end{array}$

7 Declarations and Reach $\quad 83$

8 Simple Arrays and Methods of Search 97

9 Some Applications of Arrays $\quad 111$

10 Hierarchy, Procedures and Parameters 129

11 Recursion $\quad 149$

12 Real Numbers 164

13 Some Useful Constructions 184

14 Records and Files 199

15 Problem Definition and Program Documentation 213

$\begin{array}{ll}\text { Further Reading } & 227\end{array}$

Answers to Selected Examples $\quad 229$

$\begin{array}{ll}\text { Index } & 249\end{array}$ 


\section{Preface}

The title of this book is carefully chosen - the main topic is the art of solving problems by programming. The book is intended to appeal to those who believe, like the author, that there is more to this subject than mere knowledge of a programming language. Thus the 'Algol 68' of the title plays a vital but secondary supporting function.

Although much of the book is necessarily about the mechanics of writing programs, I have tried to convey some of the important ideas of programming as a practical discipline - reliability, robustness, economy (considered in a global sense) and structure, both in data and program.

Since the over-all length of the book is limited, I have included only those parts of Algol 68 that would normally be found in a first-year undergraduate course. Omissions - which the reader will be able to fill from other books devoted primarily to Algol 68 - include computing with references, unions, the definition of operators, formats, use of the backing store, and finally labels and goto commands. This selection has the additional advantage that the subset that remains is available, with minor variations of dialect, on all existing versions of Algol 68.

Mental models are of great help in understanding complex phenomena. I should perhaps make clear that the 'identifier table' described in chapter 7 is such a model. The reader can safely take this account literally, and it will help him to write correct efficient programs. Later, if he ever studies the design of compilers, he may discover that the same effect can be reached in other more complex ways.

My thanks are due to a great number of people: to two successive first-year classes at Strathclyde University who used preliminary drafts of the book as lecture notes; to Miss Agnes Wisley, who typed the manuscript; to Dr Charles Lindsey, who as referee made many helpful suggestions and to my wife, who drew sketches for the pictures, tracked down the quotations at the head of each chapter, and gave me constant encouragement. The book itself is dedicated to my mother, Mrs Vera Colin, without whom it would not have been. 


\section{Note on Exercises}

Each chapter in this book is followed by a set of exercises. The number in brackets at the beginning of each exercise is an estimate of its difficulty. The scale ranges from 0 (trivial) to 10 (hard).

The last exercise is usually marked $\mathbf{P}$ for practical. This indicates that an actual computer solution is suggested.

A suitable rate for the exercises is about one set (including the practical) each week.

The exercises marked* have worked solutions at the end of the book. 